\title{
Social Conflict and Political Violence: A Philo-Literary Appraisal of the Nigerian Situation
}

\author{
${ }^{1}$ Samuel Asuquo Ekanem, ${ }^{2}$ E. D. Simon \\ ${ }^{1}$ Ph.D, LLB (Hons), BL, Department of Educational Foundations and Administration, Cross River University of \\ Technology, Calabar-Nigeria \\ ${ }^{2}$ Ph.D, Centre for General Studies, Cross River University of Technology, Calabar-Nigeria.
}

\section{Introduction}

There is an intricate relationship between social conflict and political violence. This is anchored on the fact that both have social elements and group interest. Social conflict involves the confrontation of powers. Power takes several forms, which may be identive and assertive, altruistic and manipulative, coercive and physical among others. On the other hand, politics involves the struggle for power and this makes conflict a basic ingredient of politics. This is usually action oriented, which is intentionally meant to carry out the actor's own will against the resistance of other people, group or parties. Conflict according to Morrison and Stevenson (1971) is a "social relationship in which the actors hold logically incompatible values". So, political conflict usually involves a struggle over values, power and scarce resources. This struggle for values, power and scarce resources could result into the use of coercion or physical force, and when this method is employed, the result will be political violence.

Political violence is a product of social conflict. This is because by definition, social is intentionally taking into account other selves, power involves the capability to produce effects, and social power is an intentionally directed capability to produce effects through another person. So, social conflict is then the confrontation of social powers. But what does this view really imply? There are three ways to look at this. First, social conflict is exclusively an aspect of social power. To understand such conflict therefore, we have to deal at the level of social powers and their dialectics. Again, social conflict is not limited to hostile or antagonistic opposition, which is to say that it is not wholly a clash or coercive powers as usually implied, but of any opposing powers.

Another is the existence of violence that does not presume an underlying social conflict. Violence here connotes an intense manifestation of strength that often involves some severe physical effects. Indeed, social conflicts involve interests, and a person's interest is a vector of power; it includes his attitude and strength towards the production of effects. So, social power is a social interest that is, one oriented towards other selves.

With this understanding, we can relate more specifically to our concepts of social conflict and political violence in Nigeria. Within the psychological sphere, an interest consists of situation, actor, goal and object so, in Nigeria how is our ethnic, religious, social, economic and political interests a factor in our response to national interest? How do these affect our decisions and responses to our national needs and integration? It is within this context that we will locate an interest as a part of the dynamic motivational calculus. Its strength is generated by our needs, and its content and direction are partially learned from experience and culture and partially rational.

In Nigeria, social conflict vary as to whether they emphasis antagonizing tests of power, competition, incompatibility of interests or mutual awareness of incompatibility based on ethnicity, economic conditions, politics affiliation, resources sharing among others. This clearly indicates or establishes the fact that social conflicts are generated based on prevalent conditions of the Micro and Macro levels of the country. These conditions that manifest social conflicts are projected within the political sphere and are aggressively and antagonistically pursued with all political mights. The result of this political aggression is what usually leads to political violence in Nigeria.

This paper therefore seeks to philosophically appraise the dynamics of social conflict and political violence in Nigeria. It argues that it is the social conditions that generate social conflicts that also manifest within the political sphere to bring about political violence.

\section{Social Conflict in Nigeria: The Historical Perspective}

To be able to undertake historical analysis of social conflict in Nigeria, it is pertinent that we understand what social conflict is by way of definition.

Social conflict according to Wikipedia (2011) "is the struggle for agency or power in society". Conflict is seen as a normal way of social life rather than abnormal situation. The implication of this is that where there are two or more people of diverse interests, there will be conflict. It is on the basis of this that conflict theory 
emphasizes interests, more than norms and values in conflict. It is usually the competition over resources that cause or bring about conflict.

Nigeria as a society is composed of different groups that compete for resources. As a multi-ethnic society, Nigeria naturally is bound to experience conflict. But apart from this natural cause or reason for conflict in Nigeria, there is the historical and political aspect of social conflict in Nigeria.

Nigeria before its creation by Flora Shaw (the wife of Lord Lugard) was a "geo-political expanse of land occupied by different Kingdoms, empires, nationalities and states (Ozumba, 1999:93). This shows that to bring such diversities together as one political union will amount to laying a solid foundation for conflicts. It is on the basis of this that the late Obafemi Awolowo described Nigeria as a "geo-political expression". The implication of this is that there is no country concretely speaking that exists as "Nigeria" but rather "different nations".

Ozumba (1999) shares this view when he states that:

... the patterns of inter-group relations among the states and people of pre-colonial Nigeria can be understood in terms of geographical, ecological, cultural, economic and political differences. For example, we had the savanna south and the Sahel North with their differing ecological differences. This necessitated the mutual interdependence of the people of the different regions. While the Sahel North had the climate good for the production of groundnut, millet, rice and cereals, the Savannah South produced palm oil, cocoa, and cassava. The network of rivers connecting these different states facilitated trade and exchange of ideas....(94).

This shows that from its very foundation, Nigeria was erected on conflicts that have geographical, ecological, cultural, economic and political concretes blocks. It is this inherent conflict that has manifested in diverse ways in the Nigerian evolution as a nation.

The history of Nigeria towards independence in 1960 is a classical study in social conflicts as characterized by the opinions of the ethnic chieftains of the different regions. Indeed, while the South was ready for independence long before October 1960, the Northern region was not just ready in all spheres.

However, when Nigeria emerged as an independent nation, it was clear that the diverse cultural, ecological, geographical, economic and political differences became manifest in the ethnic based political parties that characterized the first Republic Political experiment. Indeed, the social conflicts prevalent within the period were carried into the political arena as can be seen in the political violence that consumed the First Republic. The first Military coup and counter coups that culminated in the thirty months of Nigeria's Civil War was the highpoint of political violence that has its root in social conflicts.

Basically, social conflicts in Nigeria can be classified into the pre-Nigeria or pre-colonial, the colonial and the modern. The pre-colonial era was characterized by social conflicts that have their roots in ecological, geographical, economic, cultural and political.

The colonial epoch was a fusion of diversities to create a nation that characteristically lack integration. Again, the colonial masters did not lay the basic foundation for social integration but rather fan the embers of disunity. This can be seen in the ethnic and religious consciousness that colonialism awakened in the people of the different regions. Also, the economic imbalance and the educational disparity of the ethnic nationalities was a major cause of social conflict that Nigeria inherited from colonialism.

The modern period of Nigeria is embroiled in social conflicts that have their roots traceable to ethnicity, religion, resources or economic and political. The level of poverty in Nigeria has become a threat to the existence of the country. This poverty is not due to lack of resources but is largely due to mismanagement and corruption that is prevalent in the country. The struggle to survive, which is a natural instinct of "self preservation" has made it possible to indulge in diverse social misdemeanor.

As a country, Nigeria is abundantly and greatly endowed by nature. The natural resources of the nation has not be adequately tapped and utilized for the benefit of the citizenry. This is largely due to the visionless leadership that has seized the nation for their own purpose. This has therefore created a situation of lack in the midst of abundance. And it was on the bias of this that the late Mbadiwe came up with the concept of "politics of the stomach".

The aim of this was to draw the attention of leadership to the poverty situation in the country. However, it does appear the political leadership has an unwritten tacit agreement to carry on with the "politics of poverty". This assertion is anchored on the fact that Nigeria and Nigerians should naturally have nothing to do with poverty. This is also the opinion of the Action Congress of Nigeria's (ACN) Presidential candidate, Mallam Nuhu Ribadu. Ribadu is of the view that the poverty in Nigeria is politically induced by the leadership of the country that mismanages the resources of the country. So, a scenario, where majority of the people live in abject poverty and squalor, while a few live in opulence and arrogantly display their flamboyant lifestyles to hurt the sensibilities of the majority is bound to create conflict.

The net effect of the leadership "visionlessness" has been the escalation of the poverty level of Nigerians hence; Chimaroke Nnamani observed that poverty in Nigeria has reached an alarming level. He opines that 87 percent of the Nigerian population lives below poverty line, while the country is rated 154 on the 
World Marginal poverty index out of 172 countries with 73 million, out of an estimated 120 million Nigerians living in poverty (Punch, 2003).

Nnamani therefore traced the avoidable slide in the living standard of Nigerians to the post independence era beginning from 1960. The statistics provided by Nnamani states that in 1964, over 84 percent of Nigerians were living above poverty line, but by 1980, over 28.1 percent of the population were living in poverty and the situation degenerated to 46.3 percent in 1995, and by 1996, 65.5 percent, or 67.1 million Nigerians were unable to make ends meet. But the current UNDP report show that over 90.8 million Nigerians live below poverty level (Abifarini 2004 and The Punch, 2003).

This situation contradicts the constitutional provisions as it is contained in the Fundamental Objectives and Directives Principles of State Policy, which states the political, social, economic and educational objectives of the government of Nigeria. Indeed, section 14 (2) provides that the security and welfare of the people shall be the primary purpose of government. This is further reinforced by section 16 of the constitution that guarantees free enterprise economy with some measure of government participation, that is mixed economy.

Therefore, when a government or leadership negates the principles of the constitution as is the case with the Nigerian state, there is bound to be an effect of such negation on the society. This effect often manifest in the form of social conflict. This can be seen in the massive reaction of the people against the Structural Adjustment Programme (SAP) by the Babangida regime. This social reactions or conflicts are usually natural responses to either actions or inactions of the people against the establishment that seeks to perpetuate itself on the people to their detriment. This is the confrontation of powers as it affects others. It is this social reactions or conflicts that have posed the greatest problem to the country. This is so because, the country has not been able to "weld together a unified national entity from the disparate communities whose members retain primary loyalties to smaller units, and whose leaders see this ethnic and other divisions as an advantage to themselves and their followers" (Agi:1999). Colin Legum (1979) in his view about Africa in general asserts that:

The process of nation-building is invariably accompanied by another destalizing force: raw power struggles among competing pressure groups (often communal or regional in character) striving for control of the political machine, for a greater share of economic rewards, for status, and for privilege.

This is very typical of the Nigerian contemporary situations as can be seen in the strong opposition of some elements in the Northern part of Nigeria to the emergence of Goodluck Jonathan as the President of Nigeria. Indeed, this opposition is not just for regional or national interest. It is anchored on the "greater share of economic rewards, for status, and for privilege". Ciroma, Babangida, Atiku, Gusau and all members of the Northern Political Leaders Forum (NPLF) are pursuing their own interests, and not the interest of the North through their opposition to President Goodluck Jonathan.

Also, the militancy that characterized the Niger Delta Region cannot be said to be basically of regional interest. There exists economic interest that transcends the Niger Delta Region. This economic interest is hindged on the deprivation of the people of the Niger Delta Region from maximally benefiting from the resources that come from there. The situation becomes a kind of socio-economic and political paradoxes when people from non-oil producing regions were presiding over the political and resources of Nigeria to the detriment of the owners of the resources that suffer the ecological and socio-economic negative impacts of oil exploration. The Niger Delta issue underscores the frustration- aggression theory which shows how relative deprivation, interpreted to mean a state of mind where there is a discrepancy between what men seek and what seems attainable. The greater the discrepancy, the greater their anger and their propensity to violence (Anifowose, 1982:6)

The Nigerian political and economic structures were constructed or designed with insensitivity to the social and political implications to such imbalance. It is this design, which does not reflect or capture Nigeria as one indivisible united entity that has given rise to the multi-dimensional social conflict situations in Nigeria.

\section{Political Conflict in Nigeria}

Conflict according to Chowhury (1997) is a fundamental ingredient in politics. This is so because, it is action oriented which is intended to carry out the actor's own will against any form of resistance of the other party or parties. Political conflict emerges from the clash of opposing interests. It opposes those who are more or less satisfied with the existing social order that want to conserve it, and those for whom the existing order does not suit and so desires or want to change it (Duverger, 1964). Political conflict therefore may arise out of competition for greater power or effort to maintain one's share as a member of a favourable group. This conflict may involve disputes over the distribution of authority or resources among diverse interest groups.

In Nigeria, we cannot really offer explanation for political conflict without considering the import or relevance of ethnicity or class. Several scholars have argued that the process of modernization will erode tribal loyalties or sentiments and "create a vertical differentiation of groups ranked along a societally recognized scale of superiority - inferiority" (Chowhury, 1997). The implication of this is the assumption that communal and class conflict cannot coexist. 
Operating on the assumption that the intensity of political conflict differ from the degree of social integration, it is therefore pertinent to provide clarification to the concept of integration. Integration is the creation of a national identity out of parochial identities. To Weiner (1971), integration is "the process of bringing together culturally and socially discrete groups into a single territorial unit and the establishment of national identity" (242). But to Morrison and Stevenson, integration is "the degree of cohesion that binds members to social systems together, and is generally thought of in terms of the value, institutions and communications which facilitate escalating sequences of social conflict, cooperation and consensus" (903).

This implies that the degree of social integration is intrinsically tied to the political culture of a society. Accordingly, Verba (1965) sees political culture as consisting of the system of "empirical beliefs, expressive symbols, and values which define the situation in which political action takes place". It is therefore such culture that determines the behavior of both the individual and political system. For the individual, the political culture establishes specific principles or guidelines for effective political behavior, and for the "collectivity it provides a systematic structure of values which ensures coherence in the performance of institutions and organizations" (Chowluery :12).

It is indeed the political culture of society that sets the parameters or possible political action and the degree of integration of a society usually depends on it. It is therefore, based on this that Claude Ake (1967) argues that a political system is "integrated to the extent that the minimum units... develop in the course of political integration a pool of commonly accepted norms regarding political behaviour and a commitment to the political behaviour patterns legitimized by these norms" (3). This shows that it is the commitment to these norms that provides coherence and predictability to political life. But to Karl Marx, it is the economic structure of the society that determines the pattern of integration of a society. To Weber, the basic condition or prerequisite or integration is the development of a uniform pattern of expectations among the people (152). For Durkhein (1933), the argument is that the various parts of the society must be functionally complementary to make integration achievable.

What can be discovered in all these views is the basic idea that individuals develop certain norms that determine their pattern of political behaviour. Also, institutions create these norms and equally regulate the patterns of behaviour.

To be in a better position to offer explanation on political conflict in Nigeria it is essential to look at the fundamental characteristics of the Nigerian state. Nigeria as we all know is a society we can best describle as a conglomerate, comprising of various ethnic groups. There are about two hundred and fifty (250) ethnic groups in Nigeria. There are three major ethnic groups in Nigeria (though there is a serious doubt about this among some scholars), and these are: Ibo, Yoruba and Hause-Fulani. These major ethnic groups are spread among three regions of South East, South West and North, respectively. The north is seen to be the largest in terms of population and land mass. The north is also viewed as being highly traditional, less educated, and less developed economically. The people of the north are mostly Muslims and maintain their traditional culture. The impact of their tradition can easily be seen and identified in their political institutions. Indeed, the people of the north view everything from the perspective of Islamic religion where there is no distinction between religion, tradition, politics etc.

The Ibos and Yorubas of the South have attained high levels of education and economic development due largely to their industries. Christianity is a vital force and the dominant religion of the South. Unlike the Hausa - Fulani and the Yorubas, the Ibos of the east are very receptive to change, and more inclined towards western values. In terms of education and economy, the Yorubas and Ibos are better off than the Hausa-Fulani.

Societies in both Hausa -Fulani and the Yorubas are highly stratified, while societies in the east are basically unstratified. In the east there existed no hierarchical administrative system and no centralized political structures like what exist among the Hausa -Fulani emirates of Northern Nigeria or the "Yorubua constituted monarchies" of the West" (Chowdhury,1997).

From the above analysis, it is clear that these groups differ fundamentally in several ways. These differences have had severe "impact on the way political institutions" have functioned in Nigeria (13). Despite the various social, political and cultural characteristics of the society, colonialism is seen as being responsible for the creation of these diverse characteristics in Nigeria.

Having stated this, we can therefore trace the history of political conflict to colonialism.

\section{The Colonial Era}

Historically, political conflict in Nigeria started during the colonial period. This can be seen in the way Lagos became a Crown colony in 1862. The British in 1900 split Nigerian territories into "three pieces: the colony of Lagos (Yoruba land), the protectorate of northern Nigeria, and the protectorate of Southern Nigeria. The Northern and Southern territories were amalgamated by the Act of 1914 and a single Governor-General appointed for the entire territories of the north and South. This brought about a political fusion of the north and south. 
Gradually, certain political structures were established through constitutional developments as can be seen from the Richard constitution to the independent constitutions. Indeed, the period between 1945 and 1960 was an era of struggle between the nationalists and the colonial power. However, the anti-colonial front was dismantled in 1957 when the Macpherson constitution became operational. This led to the acceleration of the twin processes of decolonization and Africanization of the civil service. The Macpherson constitution was made after consultation with native authorities. During the process of consultation, the different groups did not agree on the role of the central executive, the extent of political participation and the pace of constitutional change (14).

During this time, the North did not ask for many significant changes in the colonial structure, except devolution of power in some. But the Yorubas and Ibos demanded for drastic changes in the colonial structure and the extension of the voting suffrage. However, in "January 1950 various groups came to an agreement on certain matters like greater regional autonomy, more representative regional legislatures, and more Nigerian participation in the formulation of policy" (14). The north did obtain representation equal to the other two regions put together. So, in 1951, when the central and regional legislatures were formed, various groups started mobilizing the people of their own regions with the single aim of winning a majority in the legislature. Before 1951, the southern people had one party that was known as NCNC. This led to the spirit of tribalism that existed between the Ibos and the Yorubas in the South. The several parties that emerged between 1941 and 1951 can best be described as communal associations that could not see beyond the primordial interest of the ethnic groups that they represent. This greatly and in several ways denied the country functionally complementary integration (Chawdhury; 1997).

The post-independence Nigeria witnessed the mobilization of communal groups by political parties. At the national level there were "three communally-based regional parties" that were involved in the struggle for power to the detriment of nation. The goal of these parties were just satisfying the interest of their own communities. This led to the complete alienation of the minority. The "development of communally-based parties among the major ethnic groups also stimulated the development of communal parties among minority groups within each region (NEPU, the Boru Youth, United Middle Belt Congress). Since, national political institutions were not autonomous; the functioning of these institutions reinforced communal conflict" (Chowdhury, 1997:14).

The politicization of communal and social conflict can be seen also in the effort of the major communal parties to increase their strength through appeals to discordant and aggrieved minorities from other regions. This materialized when "the Northern peoples congress formed a coalition government at the centre with the Nigerian National Democratic Party", which was an aggrieved party in the west. This politicization of social and communal conflicts really undermined the legitimacy of the political system. With the absence of legitimacy, the issues of penetration, participation and distribution also become problematic, and thereby drastically reducing the capacity of the political system.

This pattern of regional political structures and system has remained in the country. This manifested in the post-independence crisis that culminated in the political turmoil of 1966 in Nigerian, which has its root traced to the regionalization of political system based on communal interests. This crisis started in the western region in 1962, when the federal government declared a state of emergency and appointed a commissioner to take control of the region. The particular action by the federal government generated controversy and protest led by the people of the western region that saw the withdrawal of the commissioner. This created a kind of bitterness against the federal government that was controlled by a coalition of Northern People's Congress (NPC) and National Council of Nigeria and Cameroon (NCNC).

Again, the controversy generated by the census figures of 1962 brought about a sharp division between NPC and the NCNC. The crisis and controversy of the federal election of 1964 and the western regional election of 1965 all intensified social and communal conflict among the major communal groups.

The aim of the above analysis is to show that communalism produced intense social and political conflict in Nigeria to the extent of becoming a factor in the operation of the Military. The Military Potch of $15^{\text {th }}$ January, 1966 was triggered by Ibo officers in the army who felt threatened by the action of the federal government controlled then by a coalition of NPC and NNDP. The north reacted violently when General Aguiyi Ironsi made effort to introduce a unitary system of government in the country in July 1966. This violent reaction by the northern officers was because their interests were threatened by the unitary system of government. This clearly shows that different groups were involved in protecting and promoting their own communal interests.

The are indeed several factors that intensified social and political conflicts in Nigeria. These factors include the creation of the nation-state which increased the demands of the different groups, which was rather difficult for the government to meet. Also, the Africanization and Nigerianization of the civil service intensified communal conflict in Nigeria, as diverse groups were competing for the limited vacancies that exist.

Again, the differential rates of mobilization brought about intense political conflict in Nigeria. Social mobilization by nature creates dislocations and tensions in the society. This can be seen in the words of Karl 
Deutsch when he defines social mobilization as the "process in which major clusters of old social, economic, and psychological commitments are eroded or broken and people become available for new patterns of socialization and behaviour" (1961:494).

The effect of social mobilization is simply that people are uprooted from their old settings and feel a sense of insecurity. This insecurity forces them to employ any means, either legal or illegal to achieve their objectives. Also, social mobilization generates new demands and aspirations among people. This is because the demand for scarce resources cannot keep up with the supply, so, political competition becomes a zero-sum game. Under such a situation people use their communal identity to improve their personal fortunes.

It has been argued that differential rates of mobilization among different ethnic groups increase communal conflicts. For Paul Anber showed that rapid modernization has contributed to the reinforcement of ethnic identity among the Ibos by "creating particularistic cultural attachment to the ethnic group". He further stated that the intensity of political conflict varies with the degree of modernization (1967:168).

In contemporary Nigeria, we can see the manifestation of ethnic development of political parties, and the effects of social mobilization in the country. In the second republic, the western region mobilized to have the Unity Party of Nigeria, led by Chief Awolowo; the East had Nigerian Peoples Party (NPP) led by Dr. Azikiwe while the North had the Peoples Redemption Party (PRP) led by Waziri. However, the National Party of Nigeria (NPN) was able to mobilize the minorities to join the North and other aggrieved people (minorities) from other regions to have the NPN controlled the federal government. This democratic experiment was again aborted by the military due to socio-economic factors.

This same scenario of the second republic has played itself out again. This can be seen in the ethnic and regional-based structure or the political parties in Nigeria. In the north was All Nigerian People Party (ANPP), but now it is the Congress for Progressive Change (CPC) that carries the northern agenda as can be seen in the cult-followership of the party in the north. The Action Congress of Nigeria (ACN) champion the western interest as can be seen in the performance of the party in the western region.

The All People Grand Alliance (APGA) is the party with the Ibo agenda, while Peoples Democratic Party (PDP) can be said to have a national spread through the mobilization of some aggrieved people from the other regions and the minority groups.

This political scenario has made it difficult, if not impossible for the advancement of national integration through politics. These cleavages to ethnic, communal and regional enclaves have produced leaders that lack nationalistic focus and agenda. This has generated conflicts of diverse dimensions.

\section{The Relationship between Social Conflict and Political Violence in Nigeria}

Our analysis has shown that there is a knit relationship between social conflict and political conflict in Nigeria. Politics as we have seen is the quest for power. It involves the struggle for power, which is aimed at controlling the resources of the state. So, where there is political conflict, there is bound to be social conflict. This is because individuals and groups (social classes) within a given society have differing amounts of material and non-material resources. The powerful groups use their power to exploit other groups with less power. The two methods by which this exploitation is carried out is through brute force and economics. This creates social conflict due to the competition that exists between the rich and the poor to have access to the scarce resources available.

This competition to access or control the scarce resources usually lead to social conflict. The deprived groups usually carried this aggression to the political scenes, as they tried to stop the privileged groups from taking political power. The privileged groups realizing that it is political power that will protect and sustain their wealth usually attempt to seize political power through both legal and illegal means. This situation of the application of all means to grab political power usually lead to political violence. This can be seen in the recent cases in Akwa Ibom, Delta, Edo, Benue, Oyo and other states in Nigeria. The "do or die" mentality of the political class is usually the cause of political violence in Nigeria. This however, has a carry over effect from the social conflict that exist in every community or region. For instance, the dominance of the Ibibios in the affairs of Akwa Ibom State has generated a long standing social conflict between the Ibibios and the Annang tribe in the state. The political violence in Akwa Ibom can be traced to this long historical social conflict. This also can be said of the situation in Jos, the Plateau state capital. It is on the basis of this that Ewa argues that "political violence is a product of social conflict that has defied social solutions. It is the manifestation of the supremacy struggles that has not been logically settled within social groups that has contending economic and sociopolitical issues. There cannot be a political violence without historical antecedent in social conflict" (126).

What can be gleaned from this is the fact that social conflict often times breeds political violence. This position is anchored on Papandreou's assertion that "political violence is a product of societal anomalies that has not been adequately and satisfactorily tackled by the contending groups" (1972:146)

Indeed, political violence is a kind of socio-political interactions that has opposing elements struggling to conquer and control the social environment economically, legally, socially and politically. This also has 
ethnic colouration. It is the manifestation of the ability of politicians and would be leaders to play effectively the ethnic differnces to rise to power. Charles Tilly (1978) adds that" collective violence has flowed regularly from the political process...men seeking to seize, hold, or realign the levers of power have continually engaged in collective violence as part of their struggle". In Nigeria, this also has religious undertone as religion is one single factor apart from ethnicity that brings the people together and also pull them apart. The issue of ethnic and religious sentiments in political sphere can provoke violence of unimaginable proportion in Nigeria. It is the use of these social tools to achieve political goal that breeds political violence.

\section{Recommendations and Conclusion}

It has been established that there is a link between social conflict and political violence in Nigeria. Social conflict as we know it has its root in certain social conditions such as economic, legal, educational, political, religious and ethnic. Ethnicity and religion are two basic social activities that can easily provoke violence. The economic condition of the society is another factor that has made political office a "do or die" affair. Basically, social conflict and political violence are serious problems in Nigeria. There are various social conflicts in Nigeria that posed as mortal danger to the existence of the country as one indivisible entity. These twin monsters that can disintegrate the country need be tackled from all fronts. Therefore to curb social conflict and prevent political violence the following steps must be taken urgently by the leadership of the country;

- The social conditions and factors that create social conflict in Nigeria must be identified.

- The resources of the country must be equitably distributed among all facets of the Nigerian society.

- The Niger Delta hiccups must be given the priority attention it deserves. The area must be developed and the youths properly trained to be useful to themselves and the country.

- The leadership should address the issue of youth unemployment in the country.

- The youths must be gainfully employed instead of being used as political thugs.

- Those aspiring to be leaders must be creative enough to contribute to the development of the various tiers of governance and not only to depend on allocations from the centre.

- Nigerian leaders must display a high level of nationalistic spirit that transcends self and ethnic cleavages.

- Politicians that provide arms to the youths for political thuggery should be made to face the full wrath of the law, and there should be no sacred cows.

- There should be a level playing ground for all political office seekers. The rules should be the same for all political parties.

- The security agencies should be very neutral in the discharge of their security functions or duties.

- There must be internal democracy in all the Political Parties in the process of picking their candidates for elective offices. Imposition of candidates is the cardinal reason for disagreement among party members. This breeds conflict and usually culminate into political violence.

- There should be a systematic effort to remove religion from the state. The secular nature of the Nigerian state should be pursued with all practical constitutional rigour.

- There should be a constitutional provision that gives all the rights and privileges to every Nigerian in the state of their birth. The situation where a Nigerian is only made to enjoy the rights and privileges of aspiring to any political office in the state of his father's birth should be changed. A Nigerian can come from any state different from that of his biological parents.

- There should be a massive education of the citizenry about the electoral laws. The electorates should be made to know the value of his vote. Indeed, there should be political and electoral education of the people.

- The Independent National Electoral Commission (INEC) should be seen to be truly independent in all spheres. The tenure and salaries (funds) of the commission should be from the consolidated fund and secured.

- Incumbent political office holders should be restricted on the use of security operatives during elections.

- Political offices should be made less attractive in terms of financial gains and privileges. This is one of the major reasons that encouraged politicians to go to any extent to win elections. The reason is not to serve the people but to exploit the people. This practice must be stopped.

- The electoral processes should be made to be very transparent, which should include training in techniques about electoral conflict resolution and consensus building through courses and workshops for public officials, politicians and electoral delegates.

- There should be an institutional framework to ensure equity, transparency, accountability and service in all national affairs and functions.

- The youths of political parties should be trained in themes related to good governance and democratic culture.

- There should be a programme designed to involve working with youth with the aim to emphasis building consensus for the development of national youth agenda and inter-cultural relationships, (especially during 
the National Youth Services Corp (NYSC year) for the purpose of strengthening their capacity to civically participate in electoral processes.

- The development of methodologies and training processes to design and implement codes of ethics for electoral campaigns, particularly aimed at political leaders.

- Social conflict and political violence are vices that retard the progress of this nation. These vices have led to several loss of lives and properties. This can be seen in the Jos crisis that has led to the destruction and devastation of the once tourism destination of Nigeria. Now no one wants to go to Jos any more, and this has negatively affected the development of the place. Again, the killing of people and destruction of properties in both Ikot Ekpene and Uyo in Akwa Ibom State of Nigeria as a result of political violence in the 2011 elections show the damaging effect of these monsters.

Social conflict and political violence are twin national monsters that Nigeria should tackle with all seriousness these deserve. However, we submit that with a systematic effort through the remedies suggested here these national monsters could be tamed and Nigeria will become a peaceful place for all to live and there will be progress in the land. But for this to be, the leadership must change their mentality and be of service to the nation.

[1] Ake, C. A Political Theory Lagos: The Dorsey Press,1967

\section{References}

[2] Anber, P. "Modernization and Political Disintegration: Nigeria and the Ibos". Journal of Modern African Studies, Vol. 5, No.2, 1967.

[3] Anifowose, R. Violence and Politics in Nigeria. Enugu: Nok Publisers International,1982.

[4] Chowdhury, M. M. "Political Conflict in Nigeria" in G. O. Ozumba (Ed.) Nigeria Government and Politics. Aba: A. A. U.,1997.

[5] Ewa, M. "Political Violence in Nigeria: An Appraisal" in S. A. Ekanem and J. N. Ogar (Eds) Philosophy, Education, Science and Technology Calabar: Samroi Publishers

[6] Deutsch, K. "Social Mobilization and Political Development", American Political Science Review 55, September 1961.

[7] Duverger, Introduction a'la Politique, Paris: Gallimond.

[8] Marx, K. and Engels, F. The Communist Manifesto, authorized English Translation and Annotated by Fredrick Engels. New York: Labour News, 1964.

[9] Orison, D. G. and Stevenson . "Political Instability in Independent Black Africa: More Dimensions of Conflict Behaviour within Nations", Journal of Conflict Resolution, xv, September, 1971.

[10] Pye, L. W. "Introduction: Political Culture and Political Development in Pye and Verba (Eds.) Political Culture and Political Development, New York: Wiley and Sons, 1971.

[11] Papandreou, A. Paternalistic Capitalism, Toronto: Copp Clark,1972.

[12] Tilly, C. From Mobilization to Revolution. Massachusetts:Addison- Wesley Publishing, 1978

[13] Weber, M. The Theory of Social and Economic Organization. New York: The Free Press, 1947

[14] Weiner, M. "Political Intetgration and Development" in J. L. Finkle and R. W. Gable (Eds), Political Development and Social Change New York: John Wiley and Sons, 1971 